\author{
Tomasz JODŁOWIEC ${ }^{1}$ \\ Opiekun naukowy: Jerzy MARSZAŁEK ${ }^{2}$ \\ DOI: https://doi.org/10.53052/9788366249837.08
}

\title{
ProjeKTOWANIE WAŁU PRZEKŁADNI ZĘBATEJ WSPOMAGANE OPROGRAMOWANIEM CAD
}

\begin{abstract}
Streszczenie: W niniejszej pracy przedstawiono przykład projektowania wału wejściowego walcowej przekładni zębatej. Wypadkowy moment gnący wzdłuż osi wału wyznaczono komputerowo wykorzystując specjalny kreator komponentów przekładni mechanicznych w wybranym programie $\mathrm{CAD}$ do modelowania i projektowania 3D oraz, dla celów porównawczych, analitycznie realizując odpowiednie obliczenia wytrzymałościowe. Za pomocą kreatora wygenerowano również średnicę idealną wału. Bazując na średnicy idealnej dobrano wymiary rzeczywiste wału uwzględniając przy tym wymagania konstrukcyjne, technologiczne i montażowe. Na podstawie przeprowadzonych zadań projektowych sformułowano szereg wniosków. Przede wszystkim stwierdzono, że kreator komponentów przekładni mechanicznych jest narzędziem ułatwiającym i znacznie przyspieszającym proces projektowania wałów.
\end{abstract}

Słowa kluczowe: walcowa przekładnia zębata, projektowanie wałów, oprogramowanie CAD

\section{DESIGN OF GEAR SHAFT SUPPORTED BY CAD SOFTWARE}

\begin{abstract}
This paper presents an example of the design of the input shaft of a cylindrical spur gear reducer. The resultant bending moment along the shaft axis was determined by computer calculations using a special creator of mechanical gears components in a selected CAD software for $3 \mathrm{D}$ modelling and design, and for comparative purposes, analytically by carrying out appropriate strength calculations. Using the software, a ideal diameter of the shaft was also generated. Based on the ideal diameter, the final dimensions of the shaft were determined, taking into account the design, technological and assembly requirements. The performance of individual design tasks allowed for the formulation of a number of conclusions. It was found that the gear component creator is a tool facilitates and significantly accelerates the shaft design process.
\end{abstract}

Keywords: cylindrical spur gear, design of shafts, CAD software

\footnotetext{
1 Akademia Techniczno-Humanistyczna w Bielsku-Białej, Wydział Budowy Maszyn i Informatyki, kierunek Mechanika i Budowa Maszyn,

${ }^{2}$ dr inż., Akademia Techniczno-Humanistyczna w Bielsku-Białej, Wydział Budowy Maszyn i Informatyki,jmarszalek@ath.bielsko.pl
} 


\section{Wstęp}

Najczęściej występującym ruchem w maszynach roboczych i zmechanizowanych środkach transportu jest ruch obrotowy [1]. Powszechnie wykorzystywanymi mechanizmami podczas przekazywania ruchu obrotowego są przekładnie mechaniczne. Służą one do przenoszenia energii z wału czynnego na wał bierny, co zazwyczaj jest połączone ze zmianą momentu obrotowego, prędkości i odpowiednią zmianą sił [2]. W układach napędowych maszyn powszechnie są stosowane przekładnie zębate, w których przeniesienie napędu jest realizowane za pośrednictwem współpracujących ze sobą kół zębatych. Przystępując do projektowania przekładni zębatej najczęściej parametrami zadanymi są: moment wyjściowy (nominalny) przekładni $T_{w y j}$, charakterystyka maszyny napędzającej i napędzanej (współczynnik zastosowania $K_{A}$ ) oraz wyjściowa prędkość obrotowa $n_{w y j}$ [3]. Na podstawie tych wielkości dobiera się silnik o odpowiedniej mocy i prędkości znamionowej, wyznacza się przełożenie całkowite przekładni oraz momenty obrotowe działające na poszczególne koła zębate. Projektowanie przekładni zębatej jest zagadnieniem wieloetapowym. W pierwszej kolejności z warunków wytrzymałościowych oblicza się wymiary geometryczne kół zębatych. Na podstawie wymiarów kół zębatych i wartości sił międzyzębnych można wyznaczyć teoretyczne średnice wałów i dobrać łożyska toczne. Następnie przystępuje się do wstępnego rozplanowania wewnętrznego przekładni, w wyniku którego otrzymuje się charakterystyczne wymiary długościowe wału, tj. rozstaw podpór (odległość między łożyskami), długość wysięgowego odcinka wału (długość czopa wejściowego/wyjściowego) oraz odległość między podporą i punktem przyłożenia sił w zazębieniu [4]. Dalej można przejść do analitycznego wyznaczenia wymiarów rzeczywistych wału, tj. długości i średnicy dla poszczególnych stopni wału. W tym celu należy przygotować schemat obliczeniowy wału z uwzględnieniem wszystkich obciążeń, wyznaczyć reakcje w podporach, obliczyć wypadkowe momenty gnące, momenty skręcające oraz zastępcze momenty gnące.

Analityczne projektowanie wału może być wspomagane technikami komputerowymi. W niniejszej pracy przedstawiono przykład komputerowego wspomagania projektowania wału walcowej przekładni zębatej. W kolejnych punktach omówiono sposób wyznaczania wypadkowego momentu gnącego i zarysu teoretycznego wału z wykorzystaniem specjalnego kreatora komponentów przekładni w programie Inventor Professional.

\section{Przykład modelowania wału jednostopniowego}

Przed rozpoczęciem prac związanych $\mathrm{z}$ wygenerowaniem wału wejściowego przekładni zębatej w programie Inventor sprawdzono sposób działania, dostępnego w tym programie, kreatora komponentów przekładni mechanicznych. W tym celu z wykorzystaniem kreatora wygenerowano wykresy momentu gnącego i wykres naprężeń skręcających dla wału (rysunek 1a) o długości $a+2 b=280 \mathrm{~mm}$ (gdzie $a=80 \mathrm{~mm}$ ), którego schemat w postaci swobodnie podpartej belki prostej przedstawiono na rysunkach $1 \mathrm{~b}-1 \mathrm{~d}$. Wał został obciążony na trzy sposoby: siłą skupioną $P=1000 \mathrm{~N}$ w połowie jego długości (rysunek 1b), momentem gnącym $M=500 \mathrm{Nm}$ w połowie jego długości (rysunek 1c) oraz momentem skręcającym 
$T=125 \mathrm{Nm}$ na długości $a+b$ równoważonym przez siłę obwodową $P_{o}=5000 \mathrm{~N}$ na ramieniu $r_{o}=0.025 \mathrm{~m}$ (rysunek $1 \mathrm{~d}$ ). Na każdym schemacie zostały również zamieszczone siły reakcji $R_{A x}$ i $R_{A y}$ (w podporze A) oraz $R_{B x}$ i $R_{B y}$ (w podporze B).

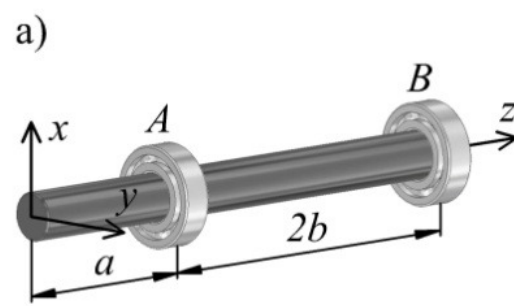

b)
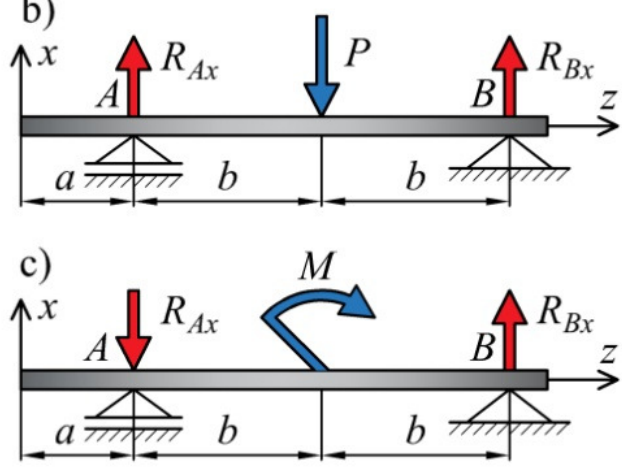

d)

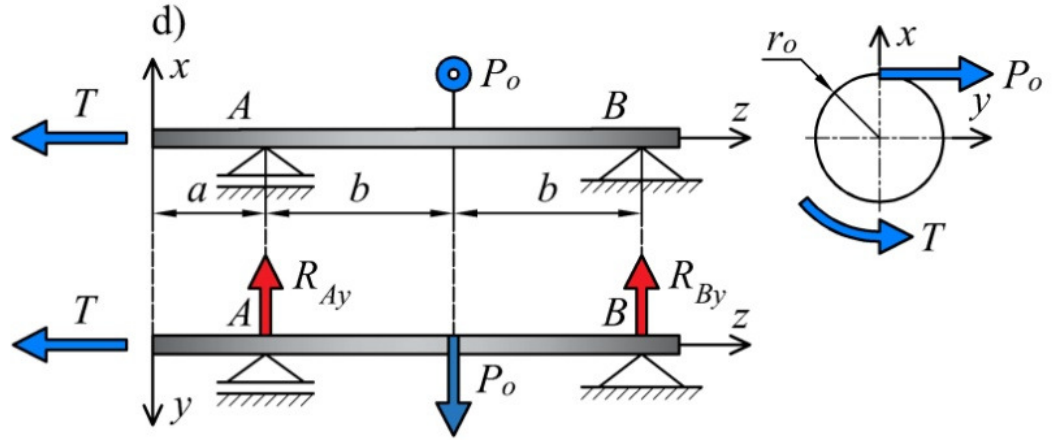

Rysunek 1. Przypadki obciażenia modelowanego watu: a) model 3D watu, b) obciązenie siła skupiona $P$, c) obciążenie momentem gnacym $M$, d) obciażenie momentem skręcajacym $T$

Projektowanie wału w kreatorze rozpoczyna się od podzielenia wału na określoną liczbę odcinków. Dla każdego odcinka definiuje się dwa wymiary, tj. długość i średnicę w przypadku przekroju kołowego. Wał o stałym przekroju poprzecznym można zamodelować za pomocą jednego odcinka. Zdefiniowanie warunków brzegowych sprowadza się do wyboru rodzaju podpory i obciążenia a następne wskazania miejsc ich położenia wzdłuż osi wału. Po wybraniu opcji ,oblicz" użytkownik ma dostęp do wyników obliczeń, m.in. wykresów przedstawiających moment gnący, ugięcie wału oraz idealną średnicę wału. Po zapoznaniu się z zasadą działania kreatora przystąpiono do zamodelowania wału obciążonego zgodnie ze schematami przedstawionymi na rysunku 1 . Wykres momentu gnącego dla wału obciążonego siłą skupioną $P$ (rysunek 1 b) został przedstawiony na rysunku 2 . Dla wału obciążonego momentem gnącym $M$ (rysunek 1c) wykres momentu gnącego przedstawiono na rysunku 3. W przypadku wału przenoszącego moment skręcający $T$ (rysunek 1d) otrzymano wykres naprężeń skręcających oraz wykres momentu gnącego od siły obwodowej $P_{o}$ w płaszczyźnie $y z$ (rysunek 4). 


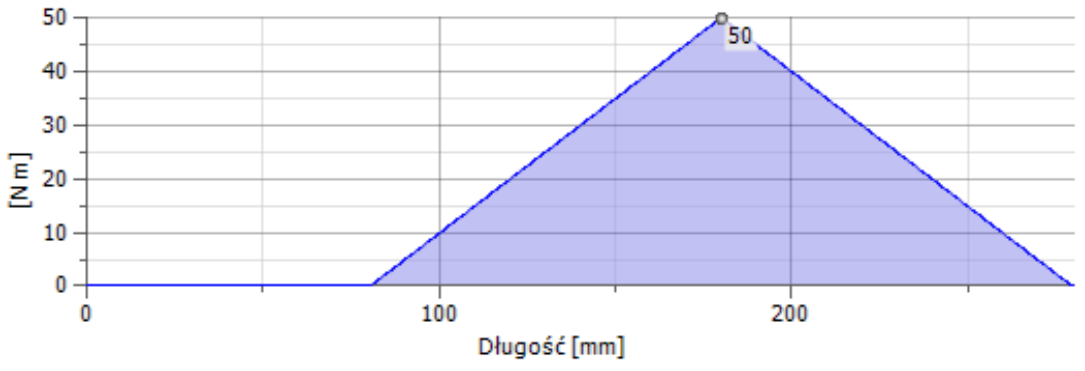

Rysunek 2. Wygenerowany w kreatorze wykres momentu gnacego dla watu obciążonego sita skupiona $P$

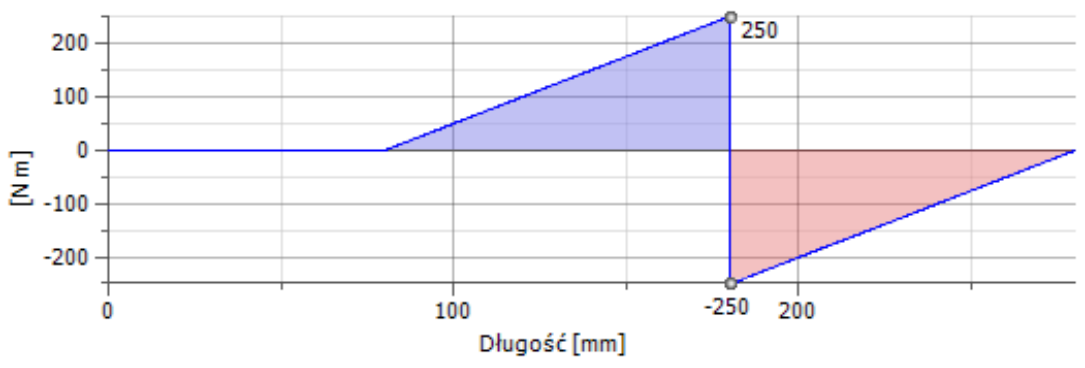

Rysunek 3. Wygenerowany w kreatorze wykres momentu gnacego dla watu obciażonego momentem gnacym $M$
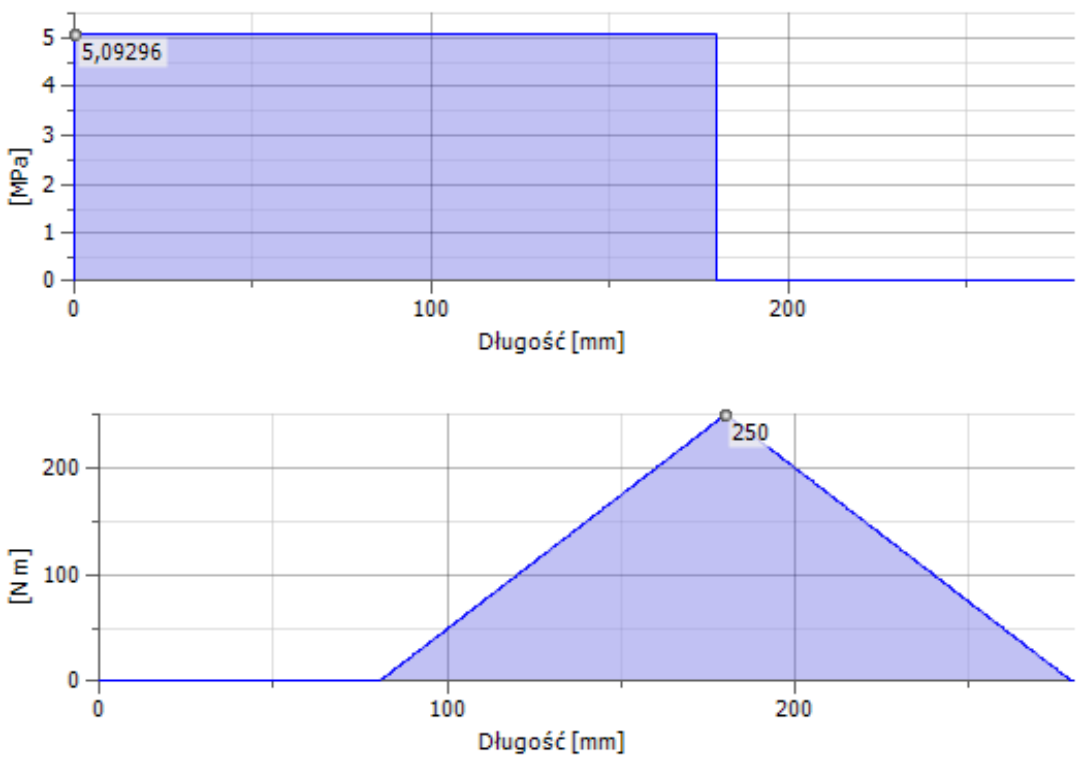

Rysunek 4. Wygenerowane w kreatorze wykresy naprężeń skręcających i momentu gnacego dla wału obciążonego momentem skręcającym $T$

Przeprowadzając obliczenia analityczne stwierdzono poprawność wygenerowanych wykresów dla analizowanych przypadków obciążenia. Zauważono, że w kreatorze nie 
ma potrzeby wprowadzania sił reakcji w podporach, ponieważ są one obliczane przez program (wystarczy tylko wskazać rodzaj i miejsce położenia podpory). W przypadku wału obciążonego momentem skręcającym $T$ (rysunek $1 \mathrm{~d}$ ) siła $P_{o}$ na ramieniu $r_{o}$ została zdefiniowana jako moment obrotowy $P_{o} \times r_{o}=125 \mathrm{Nm}$. W celu uwzględnienia efektu zginania od siły $P_{o}$ w płaszczyźnie $y z$ należało wprowadzić w kierunku osi $y$ siłę promieniową o wartości siły $P_{o}$ (rysunek 1d).

\section{Projekt wału wejściowego walcowej przekładni zębatej}

Kreator komponentów przekładni zębatych został wykorzystany do wyznaczenia wypadkowego momentu gnącego i zarysu teoretycznego wału jednostopniowej przekładni walcowej z kołami zębatymi o zębach prostych. Niezbędne do przeprowadzenia obliczeń wytrzymałościowych wału wartości obciążeń zewnętrznych i sił międzyzębnych zestawiono w tabeli 1. Wymiary charakterystyczne projektowanego wału $\left(l_{0}, l_{1}, l_{2}\right)$, dobrane na podstawie wstępnego rozplanowania wewnętrznego przekładni, oraz rozkład sił międzyzębnych działających na wał w płaszczyznach $x z$ i $y z$ przedstawiono na rysunku 5 .

Tabela 1. Moment obrotowy i sity działajace na projektowany wat przekładni

\begin{tabular}{|c|c|c|c|c|}
\hline $\begin{array}{c}\text { Dane } \\
\text { wejściowe }\end{array}$ & Oznaczenie & Nazwa & Wartość & Jednostka \\
\hline \multirow{2}{*}{$\begin{array}{l}\text { obciążenie } \\
\text { zewnętrzne }\end{array}$} & $T$ & moment obrotowy & 150 & $N \cdot m$ \\
\hline & $P_{v}$ & siła bezwładności & 600 & $N$ \\
\hline \multirow{2}{*}{$\begin{array}{c}\text { siły w } \\
\text { zazębieniu }\end{array}$} & $P_{o}$ & siła obwodowa & 6000 & $N$ \\
\hline & $P_{r}$ & siła promieniowa & 2200 & $N$ \\
\hline
\end{tabular}
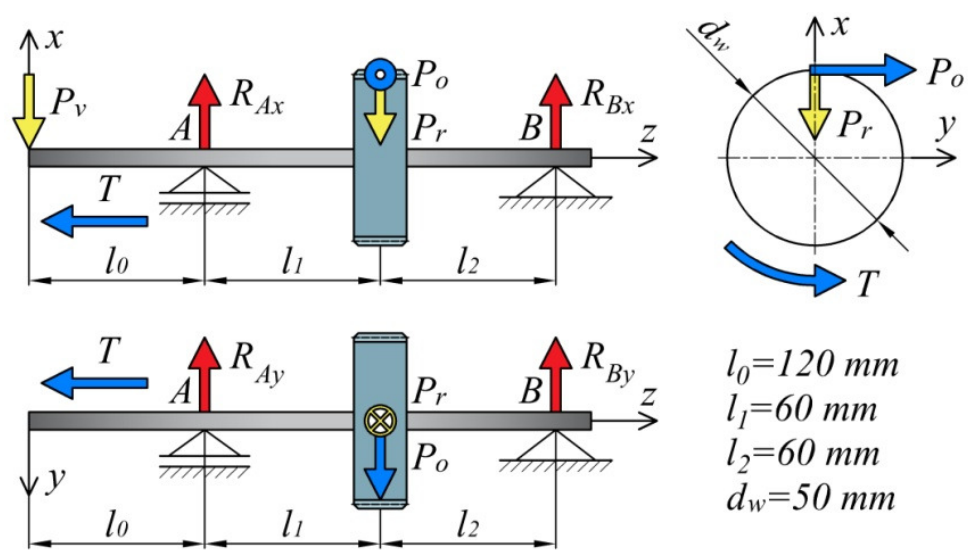

$l_{0}=120 \mathrm{~mm}$

$l_{1}=60 \mathrm{~mm}$

$l_{2}=60 \mathrm{~mm}$

$d_{w}=50 \mathrm{~mm}$

Rysunek 5. Schemat, wymiary i sposób obciążenia projektowanego wału 
W pierwszej kolejności, dla celów porównawczych, wyznaczono równania momentów gnących $M_{g x}$ i $M_{g y}$ W płaszczyznach $x z$ (1) i $y z$ (2). Wyniki obliczeń analitycznych zestawiono w tabeli 2.

$$
\begin{array}{ll}
\text { dla } z=l_{0} & M_{g x}=-P_{v} \cdot l_{0} \\
\text { dla } z=l_{0}+l_{1} & M_{g x}=-P_{v} \cdot\left(l_{0}+l_{1}\right)+R_{A x} \cdot l_{1} \\
\text { dla } z=l_{0}+l_{1}+l_{2} & M_{g x}=-P_{v} \cdot\left(l_{0}+l_{1}+l_{2}\right)+R_{A x} \cdot\left(l_{1}+l_{2}\right)-P_{r} \cdot l_{2} \\
\text { dla } z=l_{0}+l_{1} & M_{g y}=R_{A y} \cdot l_{1}(2) \\
\text { dla } z=l_{0}+l_{1}+l_{2} & M_{g y}=R_{A y} \cdot\left(l_{1}+l_{2}\right)-P_{o} \cdot l_{2}
\end{array}
$$

\begin{tabular}{|c|c|c|c|c|}
\hline \multicolumn{5}{|c|}{ Płaszczyzna $x z$} \\
\hline współrzędna $z, m m$ & $\begin{array}{c}\text { moment } \\
\text { gnaccy, } \\
N m\end{array}$ & $\begin{array}{c}\text { moment } \\
\text { skręcający, } \\
N m\end{array}$ & $\begin{array}{c}\text { siła reakcji } \\
\mathrm{R}_{\mathrm{Ax}}, N\end{array}$ & $\begin{array}{c}\text { siła reakcji } \\
\quad \mathrm{R}_{\mathrm{Bx}}, N\end{array}$ \\
\hline$z=l_{0}$ & -72 & 150 & \multirow{3}{*}{2300} & \multirow{3}{*}{500} \\
\hline$z=l_{0}+l_{1}$ & 30 & 150 & & \\
\hline$z=l_{0}+l_{1}+l_{2}$ & 0 & 0 & & \\
\hline \multicolumn{5}{|c|}{ Płaszczyzna $y z$} \\
\hline współrzędna $z, m m$ & $\begin{array}{c}\text { moment } \\
\text { gnący, } \\
N m\end{array}$ & $\begin{array}{c}\text { moment } \\
\text { skręcający, } \\
N m\end{array}$ & $\begin{array}{c}\text { siła reakcji } \\
\mathrm{R}_{\mathrm{Ay}}, N\end{array}$ & $\begin{array}{c}\text { siła reakcji } \\
\quad \mathrm{R}_{\mathrm{By}}, N\end{array}$ \\
\hline$z=l_{0}$ & 0 & 150 & \multirow{3}{*}{3000} & \multirow{3}{*}{3000} \\
\hline$z=l_{0}+l_{1}$ & 180 & 150 & & \\
\hline$z=l_{0}+l_{1}+l_{2}$ & 0 & 0 & & \\
\hline
\end{tabular}

Tabela 2. Wyniki obliczeń analitycznych

Dysponując wartościami momentów gnących $M_{g x}$ i $M_{g y}$ w płaszczyznach $x z$ i $y z$ można, dla dowolnego przekroju wału, wyznaczyć wypadkowy moment gnący $M_{g}$ korzystając ze wzoru (3). Następnie, za pomocą wzoru (4), wyznacza się zastępczy moment gnący $M_{z}$, przez co w dalszych obliczeniach uwzględnia się dodatkowe obciążenie wału w postaci momentu obrotowego $T$ (gdzie $\alpha=k_{g o} / k_{s j}$ w przypadku zachowania tego samego kierunku obrotu, $k_{g o}$ - naprężenie dopuszczalne przy zginaniu obustronnym, $k_{s j}$ - naprężenie dopuszczalne przy skręcaniu jednostronnym). W rezultacie, na podstawie zastępczego momentu gnącego $M_{z}$ i wytrzymałości materiału wału na zginanie $k_{\text {go }}$ można, korzystając z zależności (5), obliczyć średnicę teoretyczną $d_{t}$ dla dowolnego przekroju wału.

$M_{g}=\sqrt{M_{g x}^{2}+M_{g y}^{2}}$

$M_{z}=\sqrt{M_{g}^{2}+(0.5 \cdot \alpha \cdot T)^{2}}$

$d_{t}=\sqrt[3]{\left(32 \cdot M_{z}\right) /\left(\pi \cdot k_{g o}\right)}$ 
Po analitycznym wyznaczeniu średnic teoretycznych (tabela 3) przystąpiono do zamodelowania wału $\mathrm{z}$ wykorzystaniem kreatora programu Inventor. Po uruchomieniu kreatora utworzono trzy odcinki wału o jednakowej średnicy (przyjęto średnicę $\varnothing 20 \mathrm{~mm}$ ) i długościach $l_{0}, l_{1}$ i $l_{2}$ (rysunek 5) oraz wybrano rodzaje i miejsca położenia podpór i miejsca przyłożenia obciążeń działających na wał (rysunek 6a). Jednocześnie w kreatorze jest dostępny pomocniczy widok 3D (rysunek 6b).

Tabela 3. Wartości wypadkowych i zastępczych momentów gnących oraz średnic teoretycznych $w$ przekrojach charakterystycznych watu

\begin{tabular}{|c|c|c|c|c|c|c|}
\hline \multirow{2}{*}{$z, \mathrm{~mm}$} & \multirow{2}{*}{$M_{g}, \mathrm{Nm}$} & \multirow{2}{*}{$\mathrm{T}, \mathrm{Nm}$} & \multirow{2}{*}{$M_{z}, \mathrm{Nm}$} & \multirow{2}{*}{$d_{t}, \mathrm{~mm}$} & \multicolumn{2}{|c|}{ Stal C35 } \\
\cline { 1 - 1 } & & & & & $k_{g o}, M P a$ & $k_{s j}, M P a$ \\
\hline$z=0$ & 0 & 150 & 70 & $>22.22$ & & \\
\hline$z=l_{0}$ & 72 & 150 & 100.5 & $>25.07$ & \multirow{2}{*}{65} & 70 \\
\cline { 1 - 5 }$z=l_{0}+l_{1}$ & 182.5 & 150 & 195.5 & $>31.29$ & & \\
\hline$z=l_{0}+l_{1}+l_{2}$ & 0 & 0 & 0 & 0 & & \\
\hline
\end{tabular}

a)
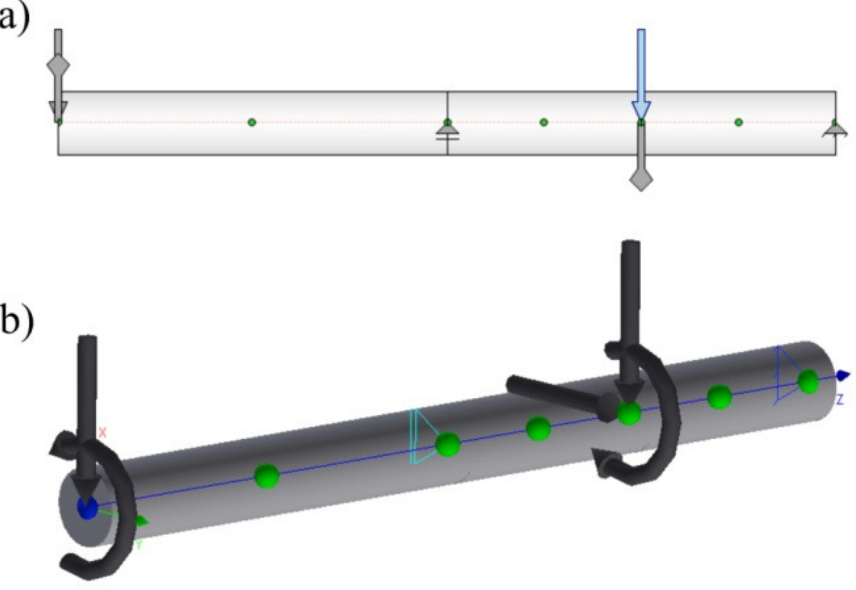

Rysunek 6. Wizualizacja projektowanego watu w kreatorze programu Inventor:

a) widok $2 D, b)$ widok $3 D$

Wygenerowany za pomocą kreatora wypadkowy moment gnący $M_{g}$ został przedstawiony na rysunku 7. Analiza porównawcza wykazała zgodność otrzymanych wartości momentu $M_{g}$ dla charakterystycznych przekrojów wału z wynikami obliczeń analitycznych (tabela 3 ). Na rysunku 8 przedstawiono, wygenerowany w kreatorze, wykres idealnej średnicy $d_{i}$ wału. Wykres ten nie zależy od wybranego materiału wału [5] (w przeciwieństwie do metody analitycznej w kreatorze nie uwzględnia się stałych $k_{g o}$ i $\left.k_{s j}\right)$. Wykres prezentuje ogólne zależności kształtu na podstawie kilku stałych naprężenia (program oblicza średnicę idealną z wynikowym naprężeniem $50 \mathrm{MPa}$ w każdej współrzędnej wału) [5]. Porównując średnicę idealną $d_{i} \mathrm{z}$ wyznaczoną analitycznie średnicą teoretyczną $d_{t}$ (tabela 3) można zauważyć istotną różnicę w przypadku wysięgowego odcinka wału $\left(d_{i}>30 \mathrm{~mm}, d_{t}>22.22 \mathrm{~mm}\right)$. Mniejsza 
różnica między $d_{i}$ i $d_{t}$ występuje w miejscu działania obciążeń międzyzębnych $\left(d_{i}>35.74 \mathrm{~mm}, d_{t}>31.29 \mathrm{~mm}\right)$.

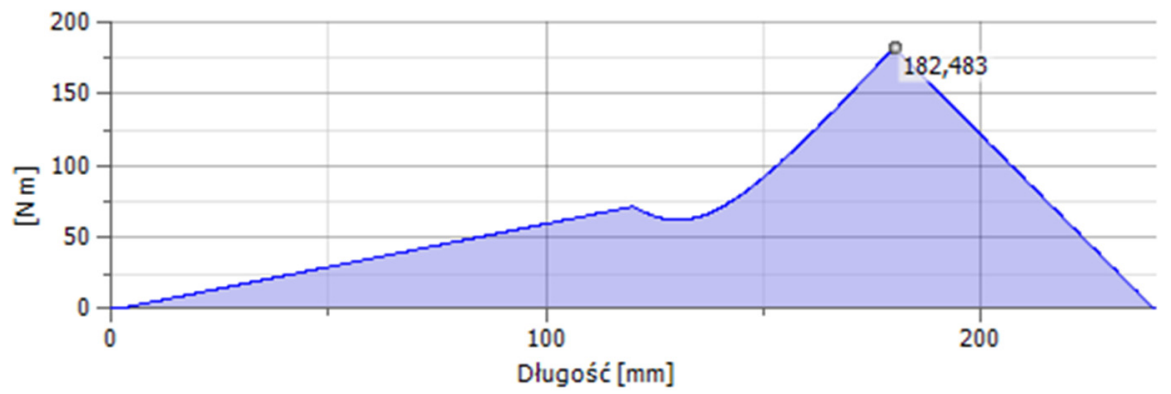

Rysunek 7. Wygenerowany $w$ kreatorze wykres wypadkowego momentu gnacego $M_{g}$ dla projektowanego watu przektadni zębatej

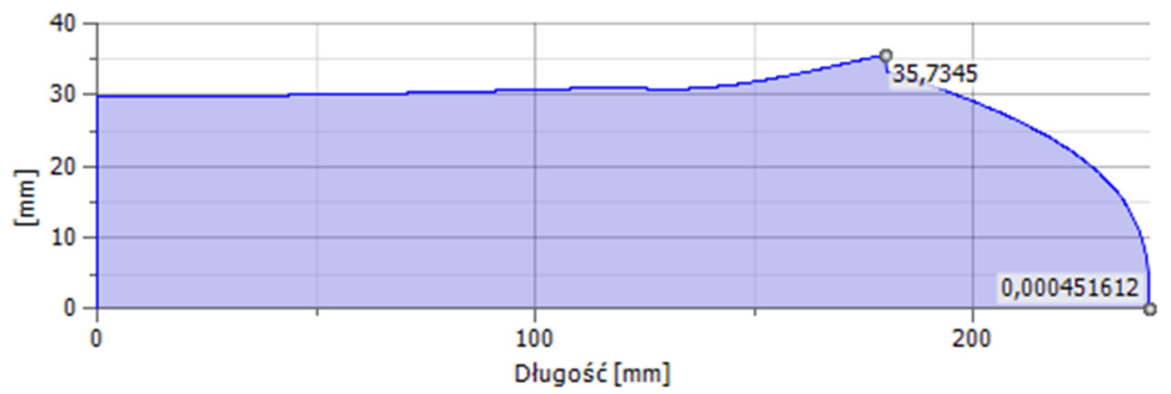

Rysunek 8. Wygenerowany w kreatorze wykres średnicy idealnej projektowanego watu przekładni zębatej

Dobierając wymiary rzeczywiste projektowanego wału należy wziąć pod uwagę dodatkowe wymagania konstrukcyjne, technologiczne i montażowe. Przykładowe wymagania, które zostały uwzględnione podczas modelowania wału, zostały zestawione w tabeli 4. Zgodnie $\mathrm{z}$ wykresem średnicy idealnej wału (rysunek 8), średnica rzeczywista wału w miejscu osadzenia łożysk tocznych powinna być większa od $30 \mathrm{~mm}$ (w tym miejscu przyjęto średnicę wału równą $35 \mathrm{~mm}$ ). Średnica wału determinuje wymiary łożysk tocznych. Szczególnie ważny jest promień zaokrąglenia łożyska $r_{z}$, od którego zależy promień podtoczenia wału $r_{w}$ (tabela 4 ). Na podstawie średnicy wysięgowego odcinka wału dobrano, zgodnie $\mathrm{z}$ zaleceniami normy, głębokość i szerokość rowka wpustowego. Z kolei długość rowka wpustowego została obliczona $\mathrm{z}$ wykorzystaniem warunku na naciski powierzchniowe [4]. W miejscu występowania sił międzyzębnych średnica idealna wału musi być większa od $35.74 \mathrm{~mm}$. Mając na uwadze średnicę okręgu tocznego zębnika $\left(d_{w}=50 \mathrm{~mm}\right)$ zdecydowano, iż projektowany wał będzie wałem zębatym. Model CAD zamodelowanego wału został przedstawiony na rysunku 9. Korzystając $\mathrm{z}$ podstawowych opcji dostępnych $\mathrm{w}$ programie Inventor sprawdzono wybrane 
właściwości fizyczne wału, tj. masę $(2.2 \mathrm{~kg})$ i moment bezładności względem osi obrotu $\left(460 \mathrm{~kg} \cdot \mathrm{mm}^{2}\right)$.

Tabela 4. Szczegółowe wymiary projektowanego wału

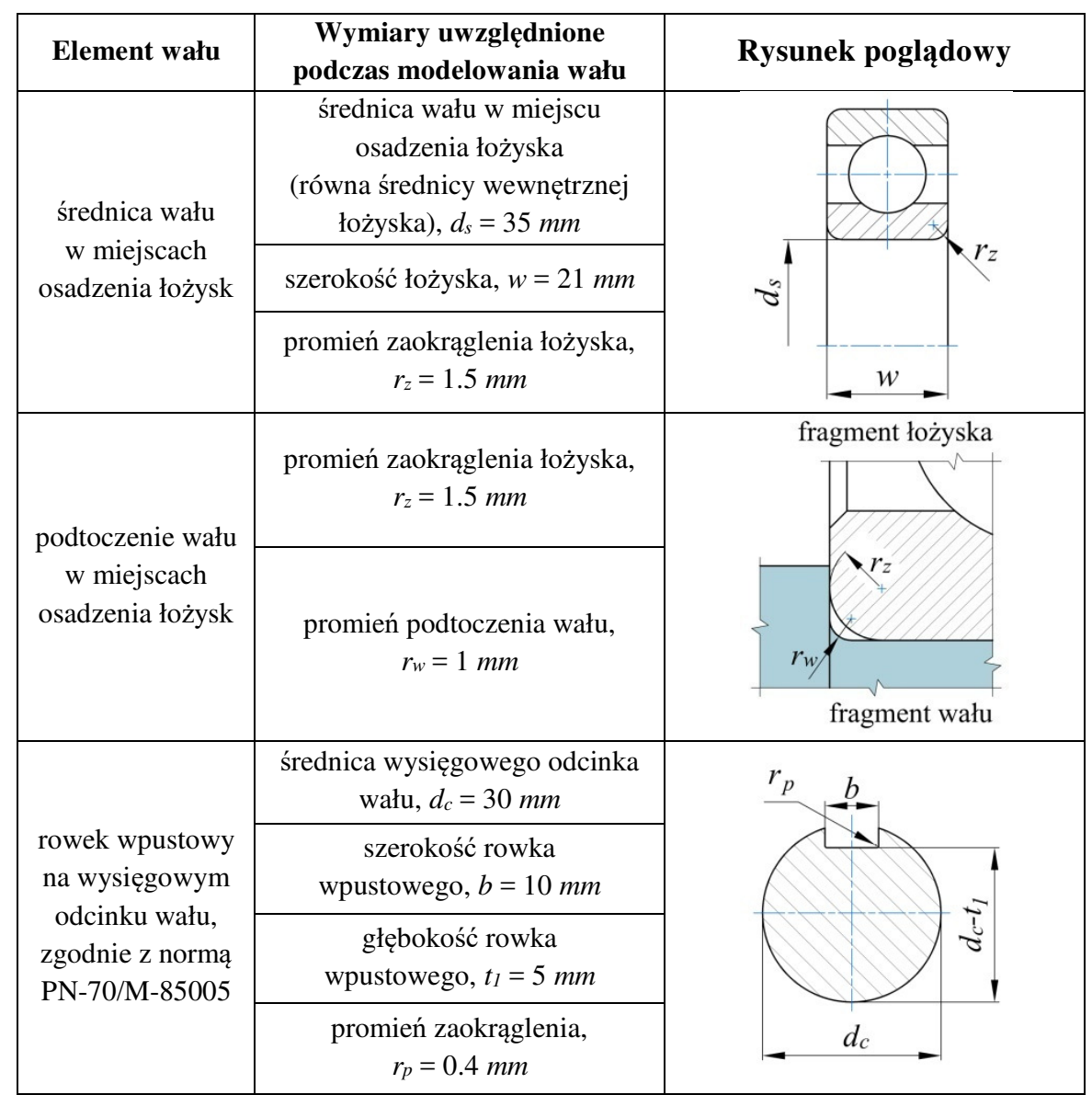

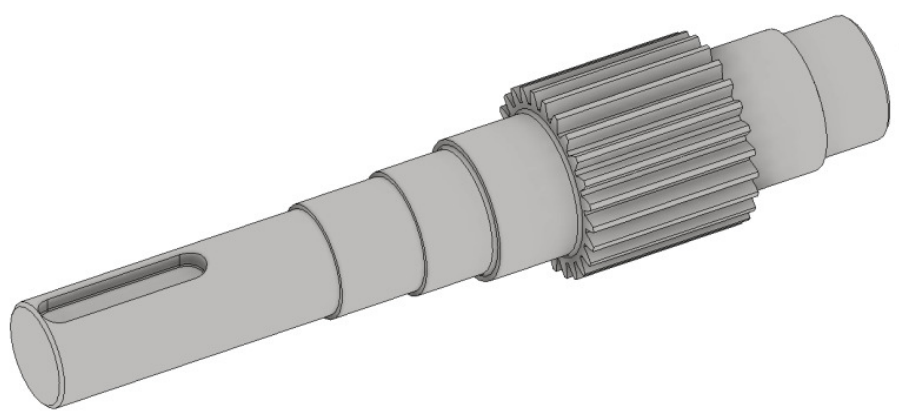

Rysunek 9. Model 3D watu na bazie wykresu średnicy idealnej wygenerowanego przez kreator programu Inventor 


\section{Wnioski}

Na podstawie przeprowadzonych zadań projektowych sformułowano wnioski:

- $\quad$ w porównaniu z metodą analityczną, otrzymanie wypadkowego momentu gnącego wzdłuż osi wału z wykorzystaniem kreatora programu Inventor nie wymaga wcześniejszego wyznaczenia sił reakcji w podporach - wystarczy wybrać rodzaj podpory i wskazać miejsce jej położenia, a wpływ sił reakcji na rozkład momentu gnącego zostanie uwzględniony automatycznie (w ten sposób można przyspieszyć proces projektowania wału),

- zaletą kreatora jest możliwość sprawdzenia wpływu masy wału na wynikowe wartości momentów gnących, co w przypadku metody analitycznej komplikuje obliczenia,

- wyznaczona za pomocą kreatora średnica idealna wysięgowego odcinka wału jest większa o 30\% w porównaniu ze średnicą teoretyczną obliczoną analitycznie - wygenerowana przez kreator średnica idealna nie zależy od właściwości materiałowych, natomiast wyznaczona analitycznie średnica teoretyczna zależy od wytrzymałości materiału na zginanie i skręcanie,

- kształtowanie końcowe wału sprowadza się do obrysowania linii teoretycznych przekrojów wału linią rzeczywistych przekrojów uwzględniając wymiary elementów przekładni otaczających wał oraz części zamontowanych na wale (są to m.in. średnica i szerokość łożysk tocznych, szerokość koła zębatego, długość połączeń wpustowych, średnica pierścienia uszczelniającego, głębokość rowków dla pierścieni osadczych sprężynujących).

Należy mieć na uwadze, że projektowanie wału przekładni mechanicznej, oprócz przedstawionych $\mathrm{w}$ niniejszej pracy niezbędnych obliczeń wytrzymałościowych, wymaga przeprowadzenia obliczeń zmęczeniowych. Sprawdzenie zmęczeniowej wytrzymałości wału polega na obliczeniu współczynnika bezpieczeństwa w przekrojach przewidywanego złamania zmęczeniowego wału [4].

\section{LITERATURA}

1. RUTKOWSKI A.: Części maszyn. WSiP, Warszawa 2008.

2. PŁUCIENNIK P., MACIEJCZYK A.: Wpływ doboru materiału przekładni zębatej na aspekty techniczno-ekonomiczne. Autobusy. Eksploatacja i testy, 6(2017), 1038-1040.

3. DREWNIAK J.: Projektowanie kół zębatych walcowych, stożkowych i ślimakowych wg norm ISO. Wydawnictwo Akademii TechnicznoHumanistycznej w Bielsku-Białej, Bielsko-Biała 2009.

4. KURMAZ L.W., KURMAZ O.L.: Projektowanie węzłów i części maszyn. Wydawnictwo Politechniki Świętokrzyskiej, Kielce 2006.

5. POMOC PROGRAMU INVENTOR [dostęp: 18.10.2021]: http://help.autodesk.com/view/INVNTOR/2021/PLK/ 